\title{
Dysregulation of peritoneal cavity B1a cells and murine primary biliary cholangitis
}

\author{
Yan-Qing Yang1, Wei Yang ${ }^{1}$, Yuan Yao ${ }^{1}$, Hong-Di Ma ${ }^{1}$, Yin-Hu Wang ${ }^{1}$, Liang Li ${ }^{1}$, \\ Qingfa Wu ${ }^{2}$, M. Eric Gershwin ${ }^{3}$ and Zhe-Xiong Lian ${ }^{1,4}$ \\ ${ }^{1}$ Liver Immunology Laboratory, Institute of Immunology and The CAS Key Laboratory of Innate Immunity and Chronic \\ Disease, School of Life Sciences, University of Science and Technology of China, Hefei, China \\ 2 The CAS Key Laboratory of Innate Immunity and Chronic Disease, School of Life Sciences, University of Science and \\ Technology of China, Hefei, China \\ ${ }^{3}$ Division of Rheumatology, Allergy and Clinical Immunology, University of California at Davis School of Medicine, Davis, CA, \\ United States of America \\ ${ }^{4}$ Innovation Center for Cell Signaling Network, Hefei National Laboratory for Physical Sciences at Microscale, Hefei, China \\ Correspondence to: Zhe-Xiong Lian, email: zxlian $1 @$ ustc.edu.cn
}

Hong-Di Ma, email: mahongdi@ustc.edu.cn

Keywords: Bla cell, autoimmune cholangitis, dysregulation, Breg, peritoneal cavity, Immunology and Microbiology Section, Immune response, Immunity

Received: March 15, $2016 \quad$ Accepted: April 13, $2016 \quad$ Published: April 20, 2016

\section{ABSTRACT}

Primary biliary cholangitis (PBC) is a chronic autoimmune liver disease with progressive cholestasis and liver fibrosis. Similar to human patients with $\mathrm{PBC}, \mathrm{p}^{4} \mathrm{O}^{-/-}$ $I L-2 R^{-/-}$mice spontaneously develop severe autoimmune cholangitis. Although there has been considerable work on immune regulation and autoimmunity, there is a relative paucity of work directed at the functional implications of the key peritoneal cavity (PC) B cell subset, coined B1a cells in PBC. We used flow cytometry and highresolution microarrays to study the qualitative and quantitative characteristics of $B$

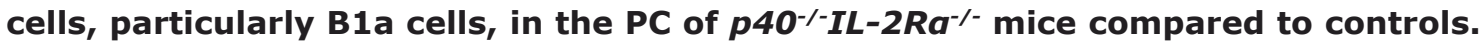
Importantly, B1a cell proliferation was markedly lower as the expression of Ki67 decreased. Meanwhile, the apoptosis level was much higher. These lead to a reduction

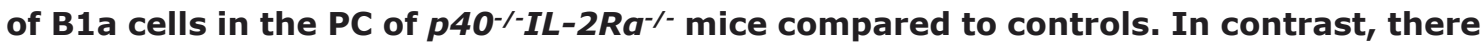
was a dramatic increase of $\mathrm{CD4}^{+}$and $\mathrm{CD8}^{+} \mathrm{T}$ cells accompanied by elevated production of IFN-Y. In addition, we found a negative correlation between the frequency of $B 1 a$ cells and the presence of autoreactive $\mathrm{CDB}^{+} \mathrm{T}$ cells in both liver and $\mathrm{PC}$ of $\mathrm{p40}^{-}$

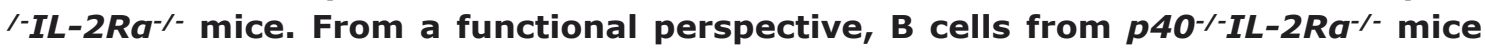
downregulated IL-10 production and CTLA-4 expression, leading to loss of B cell regulatory function. We suggest that the dysfunction of B1a cells in the PC in this murine model of autoimmune cholangitis results in defective regulatory function. This highlights a new potential therapeutic target in PBC.

\section{INTRODUCTION}

It is interesting that the liver, whose immunological function is to facilitate immune tolerance, itself becomes a victim of autoimmunity, including primary biliary cholangitis (PBC), a disease characterized by lymphocytic infiltrates in portal tracts and the presence of antimitochondrial Abs (AMAs) secreted by autoreactive B cells [1-7]. A major difficulty in understanding $\mathrm{PBC}$ is that the latency time between the onset of autoantibodies and the appearance of clinical disease may lag by years. Thus the use of murine models has become particularly important in defining the earliest events that lead to portal inflammation [8-12].

An interesting feature of both humans and mice with autoimmune cholangitis is that although there are 
Table 1: Cell number of immune cell subsets in the peritoneal cavity

\begin{tabular}{|l|l|l|}
\hline \hline & $p 40^{-} I L-2 R \alpha^{+-}$ & $p 40^{-} I L-2 R \alpha^{-/}$ \\
\hline Total cell number $\left(\mathrm{n} \times 10^{6}\right)$ & $4.78 \pm 1.46$ & $7.58 \pm 3.10^{*}$ \\
\hline T cell & $0.30 \pm 0.14$ & $3.87 \pm 2.86^{* *}$ \\
\hline $\mathrm{CD}^{+}$T cell & $0.21 \pm 0.11$ & $1.53 \pm 0.99^{* * *}$ \\
\hline $\mathrm{CD} 8^{+}$T cell & $0.06 \pm 0.01$ & $2.29 \pm 1.91^{* *}$ \\
\hline B cell & $1.95 \pm 0.71$ & $0.59 \pm 0.48^{* * *}$ \\
\hline NK cell & $0.07 \pm 0.06$ & $0.02 \pm 0.02^{*}$ \\
\hline Macrophage & $2.04 \pm 0.75$ & $2.23 \pm 0.61$ \\
\hline
\end{tabular}

*, $P<0.05$; **, $P<0.01$; ***,$P<0.001$, compared with $p 40^{-}-I L-2 R \alpha^{+/-}$mice.

high titer AMAs, the role of B cells in the pathogenesis of disease has remained enigmatic [13-16]. Previous work on B cells in a variety of murine models of autoimmunity have emphasized that there are two distinct $\mathrm{B}$ cell lineages, including $\mathrm{B} 1$ (including $\mathrm{B} 1 \mathrm{a}$ and $\mathrm{B} 1 \mathrm{~b}$ ) and $\mathrm{B} 2$. These populations arise from distinct progenitors and differ in development, tissue distribution, phenotype and function [17-19]. Importantly, B cell populations include a regulatory subpopulation whose function and clinical importance continues to be defined [20-24]. In addition, there is a unique $\mathrm{B}$ cell subpopulation, namely the B1 cells, is enriched in the PC. This subpopulation contributes to immune regulation through spontaneous production of natural antibodies, and can function as an antigenpresenting cell [25-33]. Our laboratory has focused on a unique model of PBC, $p 40^{--I L-2 R \alpha^{-/}}$mice [12]. This model not only manifests severe portal inflammation/bile duct damage, but also develops liver fibrosis. We have focused on the role of B1 cells in this model and report herein a contribution of B1a cell dysfunction to the loss of tolerance by alteration of regulatory pathways. These data take on significance not only for $\mathrm{PBC}$, but also focus in further defining the mechanisms of immune tolerance and B1 subpopulations.

\section{RESULTS}

\section{Quantitation of PC subsets}

As expected, and for the purpose of control only, we noted significant portal infiltrates and bile duct injury in the liver of 12 week old $p 40^{-} I L-2 R \alpha^{-/}$mice (Figure 1A). Total number of PC cells was markedly increased in $p 40^{-}-I L-2 R \alpha^{-/}$mice, compared to $p 40^{--} I L-2 R \alpha^{+/}$mice $(P=0.0216$, Figure 1B and Table 1). The numbers of T cells $(P=0.0015), \mathrm{CD}^{+} \mathrm{T}$ cells $(P=0.0008)$ and $\mathrm{CD} 8^{+}$ $\mathrm{T}$ cells $(P=0.0024)$ were much higher in PC of $p 40^{-1-}$ $I L-2 R \alpha^{-/}$compared to $p 40^{-\digamma} I L-2 R \alpha^{+/-}$mice, while $\mathrm{B}$ cell number $(P<0.0001)$ was dramatically lower (Figure
1C, 1D and Table 1). In PC CD4 $4^{+}$and $\mathrm{CD} 8^{+} \mathrm{T}$ cells, Th1 cell associated cytokine IFN- $\gamma$ was higher in $p 40^{-1-}$ $I L-2 R \alpha^{-/}$mice compared to $p 40^{-}-I L-2 R \alpha^{+/}$controls $(\mathrm{P}=$ $0.002 \& P<0.0001$ ) (Figure 1E). As noted earlier, we initially compared control mice with 3 genotypes and found them similar in liver histology, cell number and cytokine secretion (Figure S1). Thence we used littermate $p 40^{--} I L-2 R \alpha^{+/}$mice as controls throughout these studies. We thought that the change of PC cell subsets in $p 40^{-1-}$ $I L-2 R \alpha^{-/}$mice might be resulted from the inflammatory environment of PC. To support our hypothesis, we analyzed the level of inflammatory cytokines in PC. Importantly, the concentrations of TNF and MCP-1 were significantly increased in PC lavage fluid of $p 40^{--} I L-2 R \alpha^{-/}$ mice compared to $p 40^{-/} I L-2 R \alpha^{+/}$mice $(P<0.0001 \& P$ $<0.0001$, Figure 1F). These data showed a significant quantitative difference in the PC subpopulations of $p 40^{-}$ ${ }^{\prime} I L-2 R \alpha^{-/}$mice.

\section{Correlation of portal inflammation and B1a cell frequency}

Using correlation analysis, we noted that PC cell number was positively correlated with the number of liver MNCs $(P=0.0120$, Figure $2 \mathrm{~A})$ in $p 40^{-} I L-2 R \alpha^{-/}$mice, and the frequency of $\mathrm{B} 1 \mathrm{a}$ in $\mathrm{B}$ cells was negatively correlated with $\mathrm{PC}$ and liver MNC numbers $(P=0.0300$ and $P=$ 0.0344 , Figure $2 \mathrm{~B}, 2 \mathrm{C})$. In addition, there was a negative correlation between the frequency of $\mathrm{B} 1 \mathrm{a}$ in $\mathrm{B}$ cells and the frequency of $\mathrm{CD} 8^{+} \mathrm{T}$ cells in $\mathrm{PC}$ and liver $(P=0.0030$ and $P=0.0426$, Figure 2D, 2E). Taken together, these data reflected that $\mathrm{B} 1 \mathrm{a}$ cell population was negatively correlated with portal inflammation in $p 40^{-} I L-2 R \alpha^{-/}$mice.

\section{Change of B1a cell population with age}

The frequency of B1a $\left(\mathrm{CD} 11 \mathrm{~b}^{+} \mathrm{CD}^{+}\right)(P<0.0001)$ and $\mathrm{B} 1 \mathrm{~b}$ cells $\left(\mathrm{CD} 11 \mathrm{~b}^{+} \mathrm{CD} 5^{-}\right)(P<0.0001)$ in $\mathrm{B}$ cells were much lower in $p 40^{--} I L-2 R \alpha^{-/}$mice compared with $p 40^{--}$ 
(A) $\quad$ p40-IIL-2Ra ${ }^{+/-}$

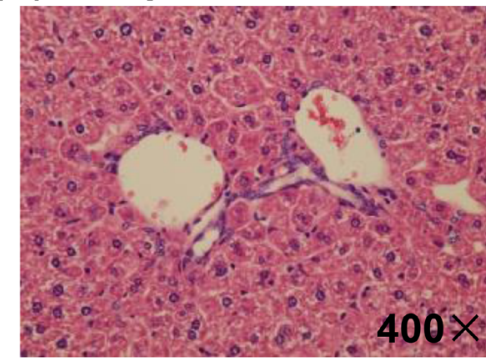

p40-IL-2Ra ${ }^{-/-}$

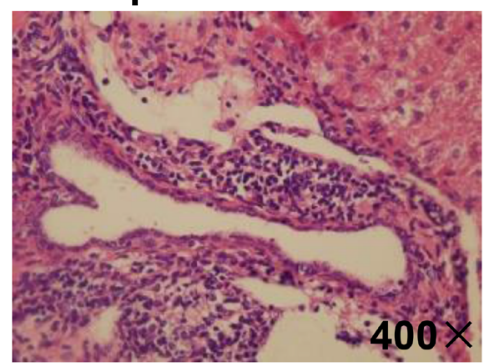

(B)

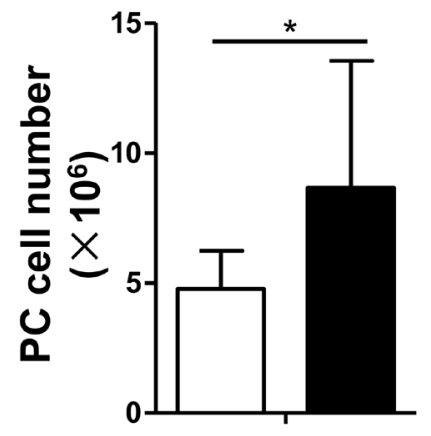

(D)
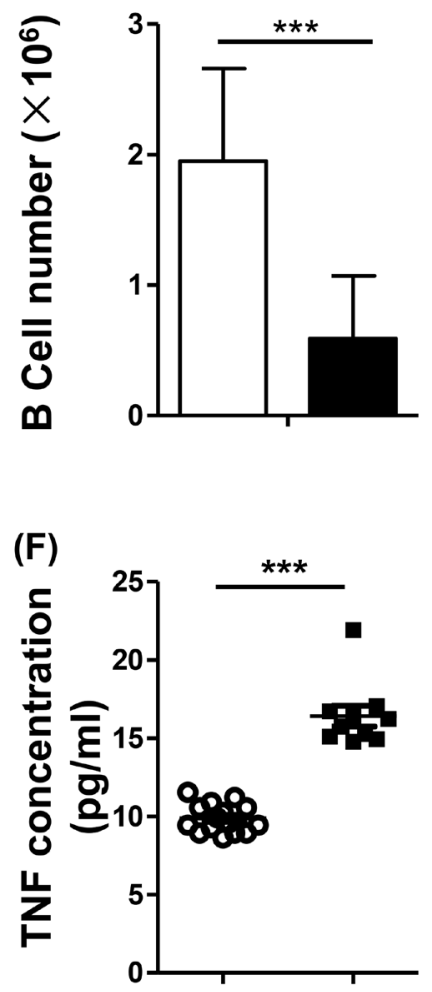

(C)

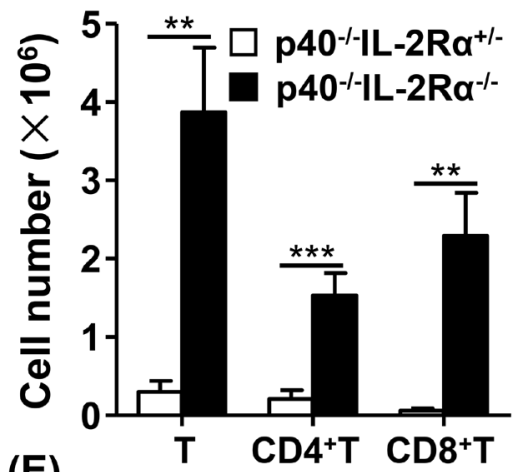

(E)
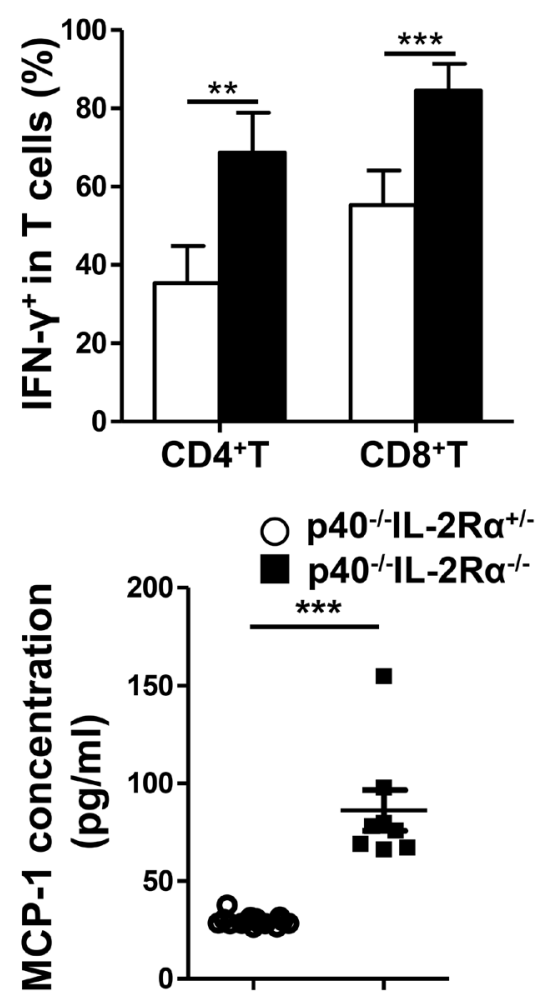

Figure 1: There was a decrease of B cells, an increase of total cells, including T cells, in the PC of $p 40^{-} I L-2 R \alpha^{-/}$mice. A. $\mathrm{H} \& \mathrm{E}$ staining of liver sections from $p 40^{-} I L-2 R \alpha^{-/}$mice and $p 40^{-} I L-2 R \alpha^{+/}$mice. B. Numbers of total cells in the PC of $p 40^{-} I L-2 R \alpha^{-/}(n=$ 13) and $p 40^{-} I L-2 R \alpha^{+/}$mice $(n=9)$. Total number of T cells, CD $4^{+} \mathrm{T}$ cells, CD $8^{+} \mathrm{T}$ cells $\mathbf{C}$. and B cells $\mathbf{D}$. in the PC of $p 40^{-} I L-2 R \alpha^{-/}$mice $(n=5)$ and $p 40^{-} I L-2 R \alpha^{+/}$mice $(n=9)$. E. The frequency of IFN- $\gamma^{+}$cells gated on $\mathrm{CD}^{+}$and $\mathrm{CD} 8^{+} \mathrm{T}$ cells in PC of $p 40^{-} I L-2 R \alpha^{-/}$mice $(n$

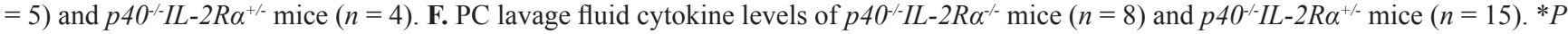
$<0.05, * * P<0.01, * * * P<0.001$. 
$I L-2 R \alpha^{+/}$mice. B1a cells were almost undetectable, and the frequency of B2 (CD11b-CD5 $)$ cells $(P<0.0001)$ in B cells were higher in $\mathrm{PC}$ from $p 40^{--} I L-2 R \alpha^{-/-}$mice compared to $p 40^{-/} I L-2 R \alpha^{+/-}$mice (Figure $3 \mathrm{~A}, 3 \mathrm{~B}$ ). We also detected another PBC mouse model, the $d n T G F \beta R I I$ mice, and found similar phenomenon that the frequency of B1a cells was decreased in PC of $d n T G F \beta R I I$ mice $(P=0.0238$, Figure S3A). The numbers of B1a $(P<0.0001)$ and B1b cells $(P<0.0001)$ were markedly reduced in $p 40^{--} I L$ $2 R \alpha^{-/}$mice compared with $p 40^{-/} I L-2 R \alpha^{+/}$mice, whereas the number of $\mathrm{B} 2$ cells $(P=0.3752)$ was not altered (Figure $3 \mathrm{C})$. We also found the number of total B cells $(P$ $=0.0214$, Figure $\mathrm{S} 2 \mathrm{~A}$ ) was decreased in spleen of $p 40^{--} I L-$
$2 R \alpha^{-/}$mice. But the frequency of B1a $(P=0.8113), \mathrm{B} 1 \mathrm{~b}$ $(P=0.3832)$ and B2 $(P=0.5434)$ cells in spleen B cells did not change (Figure S2B). The frequency of B1a cells decreased gradually with age in $p 40^{-/-} I L-2 R \alpha^{-/}$mice, and was always significantly lower when compared with that of $p 40^{--} I L-2 R \alpha^{+-}$mice at the same age $(P<0.002$, Figure 3D). B1 a cells from $p 40^{-/} I L-2 R \alpha^{-/}$mice expressed lower levels of $\operatorname{Ki67}(P=0.0162$, Figure 3E) and exhibited higher level of apoptosis $(P=0.0259$, Figure $3 \mathrm{~F})$. The frequency of Annexin $\mathrm{V}^{+} 7-\mathrm{AAD}^{-}$early stage apoptotic B1a cells $(P=0.4089)$ did not change, but the frequency of Annexin $\mathrm{V}^{+} 7-\mathrm{AAD}^{+}$late stage apoptotic B1a cells $(P$ $=0.0284$ ) was significantly increased in the $\mathrm{PC}$ of $p 40^{-}$
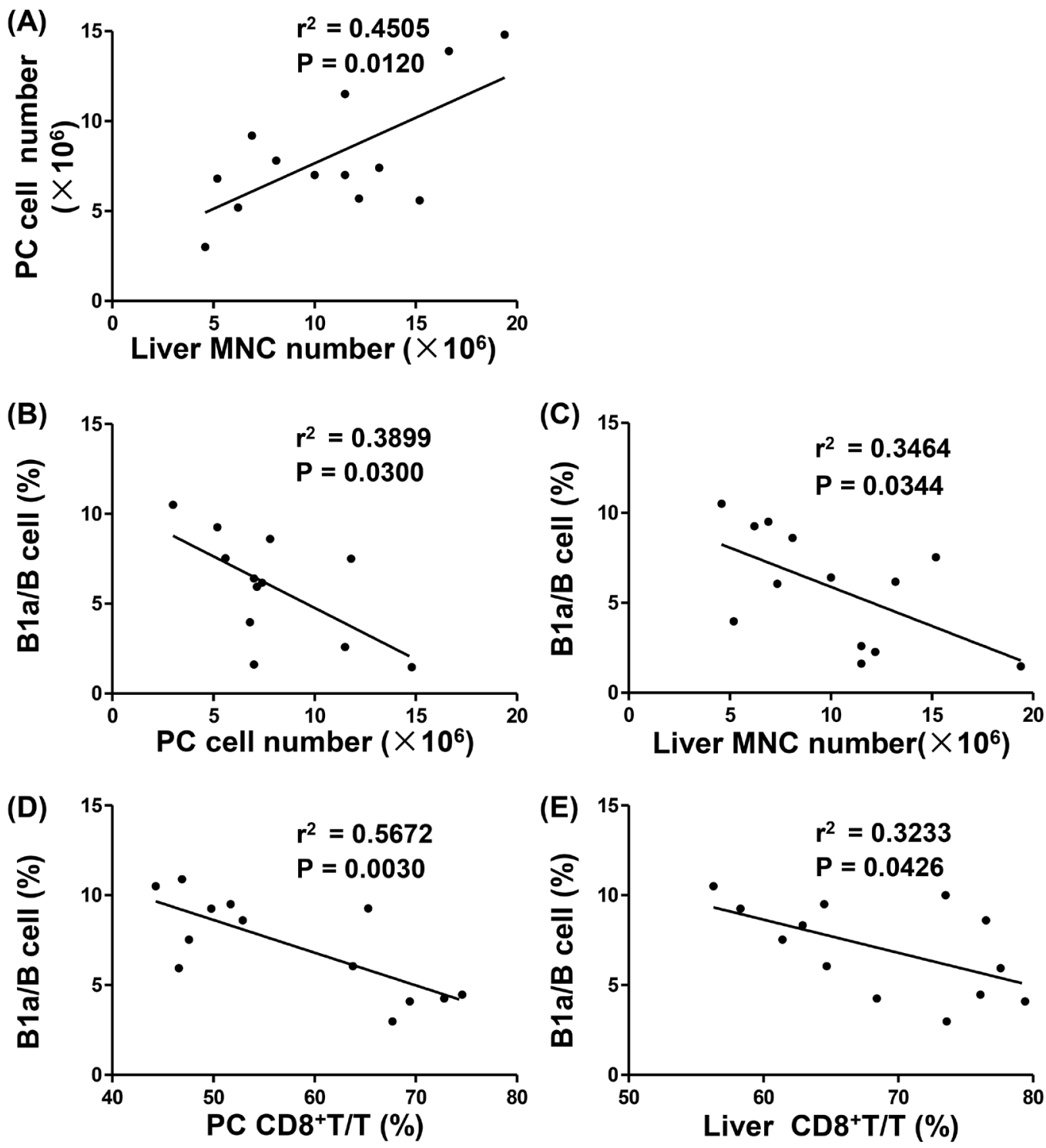

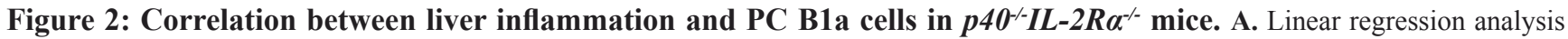
between PC cell numbers and liver MNC numbers of $p 40^{--} I L-2 R \alpha^{-/}$mice $(n=13)$. Linear regression analysis between the ratio of $\mathrm{B} 1 \mathrm{a} / \mathrm{B}$ cells and cell numbers in PC $(n=12) \mathbf{B}$. and liver $(n=13) \mathbf{C}$. of $p 40^{-/} I L-2 R \alpha^{-/}$mice. Linear regression analysis between the ratio of B1a/B cells and the ratio of CD $8^{+} \mathrm{T} / \mathrm{T}$ cells in PC D. and liver $\mathbf{E}$. of $p 40^{-/} I L-2 R \alpha^{-/}$mice $(n=13)$. 
${ }^{-} I L-2 R \alpha^{-/}$mice. These data demonstrated a positive correlation of the change in B1a cell frequency and disease progression in $p 40^{-/} I L-2 R \alpha^{-/}$mice.

\section{Reduction of expression of CTLA-4, GITR and IL-10 secretion in PC B cells of $p 40^{--} I L-2 R \alpha^{-/-}$mice}

B1a cells had a much higher production of IL-10 (B1a vs B1b and B1a vs B2, $P<0.001$, Figure 4A), and expression of CTLA-4 (B1a vs B1b and B1a vs B2, $P<$ 0.001 , Figure 4B) and GITR (B1a vs B1b, $P=0.0222$; $\mathrm{B} 1 \mathrm{a}$ vs $\mathrm{B} 2, P<0.001$, Figure $4 \mathrm{C}$ ) than $\mathrm{B} 1 \mathrm{~b}$ and $\mathrm{B} 2$ cells in $p 40^{--} I L-2 R \alpha^{+/-}$mice. Moreover, the secretion of IL-10, and expression of CTLA-4 and GITR were all significantly downregulated in $p 40^{-/} I L-2 R \alpha^{-/-}$B1 a cells compared with that of $p 40^{-/} I L-2 R \alpha^{+/}$mice (IL-10, $P=0.0041$; CTLA-4, $P=0.0035$; GITR, $P<0.001$, Figure 4D). There were also distinct differences in $\mathrm{B}$ cell activation markers in $\mathrm{B} 1 \mathrm{a}$ cells of $p 40^{-/} I L-2 R \alpha^{-/}$mice compared to $p 40^{-/} I L-2 R \alpha^{+/}$ mice, including CD44 and CD80 $(P=0.0006$ and $P=$ 0.007 , Figure $4 \mathrm{E}, 4 \mathrm{~F})$. Similar results were also detected in the PC B cell subsets of $d n T G F \beta R I I$ mice (Figure S3) These data suggested both qualitative and quantitative defects of B1a cells in the PC of $p 40^{--} I L-2 R \alpha^{-/}$mice.

\section{PC B1a cells in $p 40^{-/} I L-2 R \alpha^{-/}$mice overexpress inhibitory markers and reduce regulatory markers}

The B1a cell sorting purity was confirmed more than 96\% (Figure S4). The microarray data (GEO accession number GSE79190) indicated that there was a differential transcription of 381 genes which changed greater than two fold in B1a of $p 40^{--} I L-2 R \alpha^{--}$mice. Amongst these 381 genes, 154 genes were up-regulated and 227 genes were down-regulated (Figure S5A), which included cytokinecytokine receptor interactions, chemokine signaling pathways, transcription factor regulatory activity and cell cycle related genes (Figure S5B, S5C). Amongst B cell function related genes, in which the fold change were more than 1.3, Cd44, Cd80, Bcl6 and Ctla4 were downregulated. In addition, the expression of $A h r$, which could inhibit IL-10 secretion, was up-regulated. Btla, Cd72 and Cd22, which could inhibit BCR signaling transduction through the ITIM (immunoreceptor tyrosine-based inhibitory motif) domain, was also up-regulated (Figure
(A)

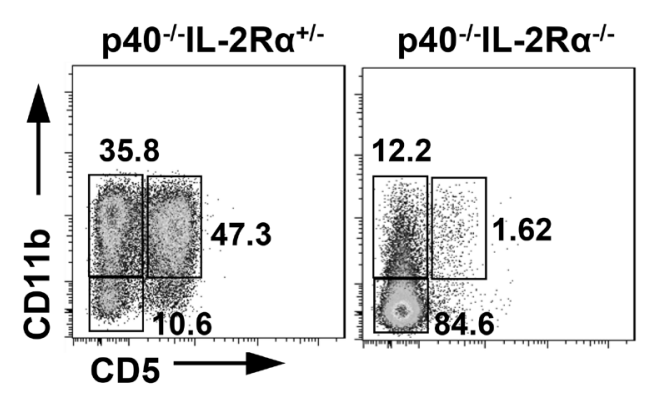

(D)

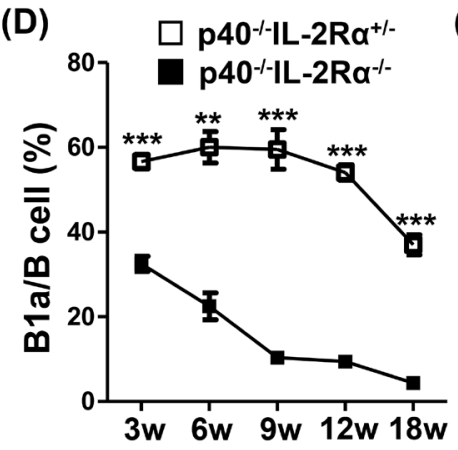

(B)

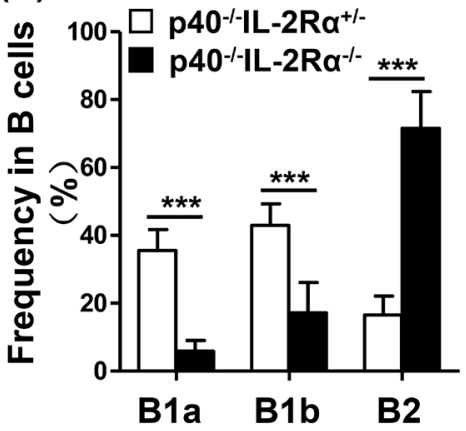

(C)

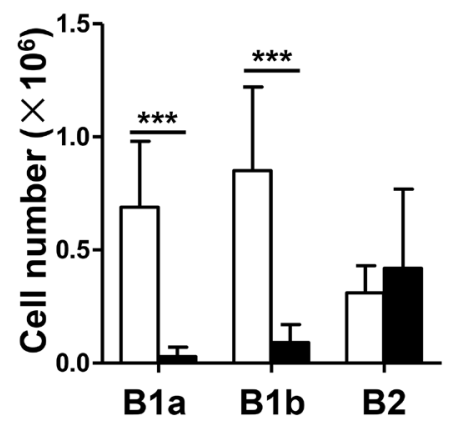

(E)

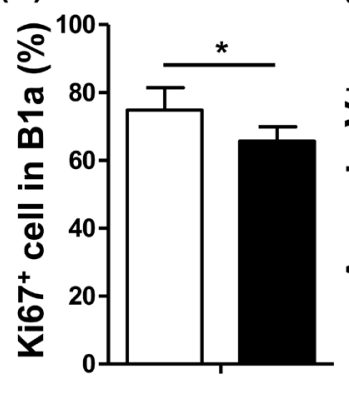

(F)
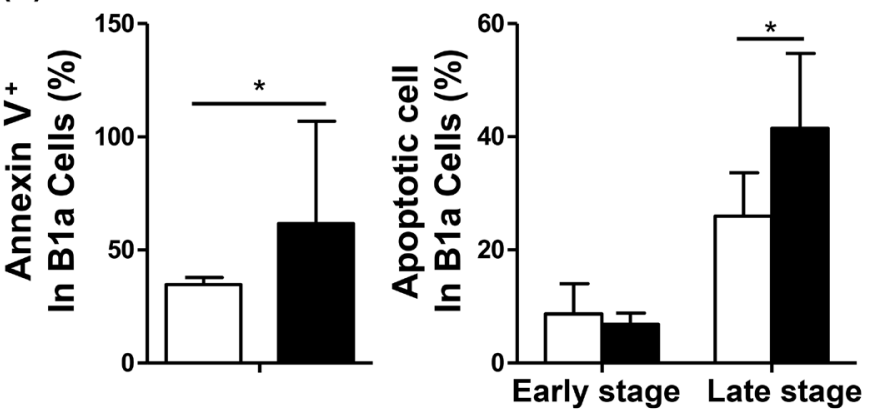

Figure 3: Comparison of B cell subpopulations in the PC of $p 40^{-/} I L-2 R \alpha^{-/}$mice and $p 40^{-/} I L-2 R \alpha^{+/-}$mice. A. A representative graph of PC B cell subsets at 18 weeks of age $p 40^{--} I L-2 R \alpha^{-/}$mice and $p 40^{-/} I L-2 R \alpha^{+/}$mice. The frequency B. and cell number C. of B1a,

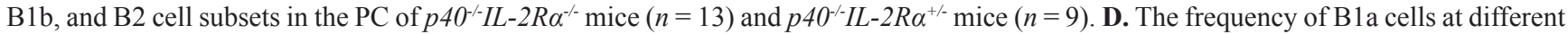
ages in PC of $p 40^{--} I L-2 R \alpha^{-/}$mice and $p 40^{--} I L-2 R \alpha^{+/}$mice (Each data point, $\left.\mathrm{n} \geq 3\right)$. E. Ki67 expression in PC B1a cells from $p 40^{--} I L-2 R \alpha^{-/}(n$ $=6)$ and $p 40^{-} I L-2 R \alpha^{+/}$mice $(n=6)$. F. The apoptosis level of PC B1a cells labeled with Annexin V and 7-AAD from $p 40^{--} I L-2 R \alpha^{--}$mice $(n=7)$ and $p 40^{--} I L-2 R \alpha^{+/-}$mice $(n=6) . * P<0.05, * * P<0.01, * * * P<0.001$. 
(A)

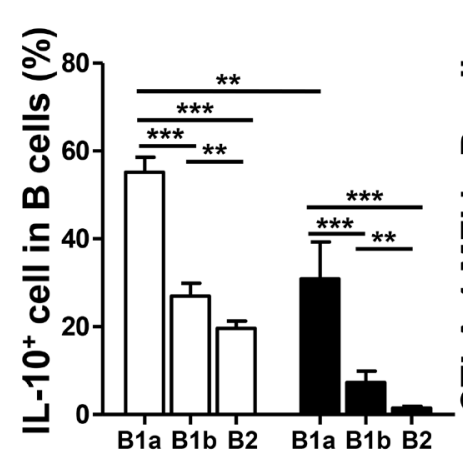

(D)

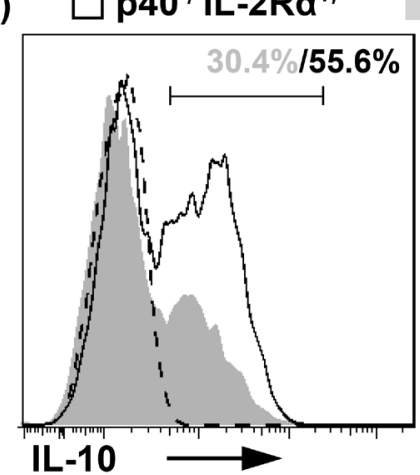

(E)
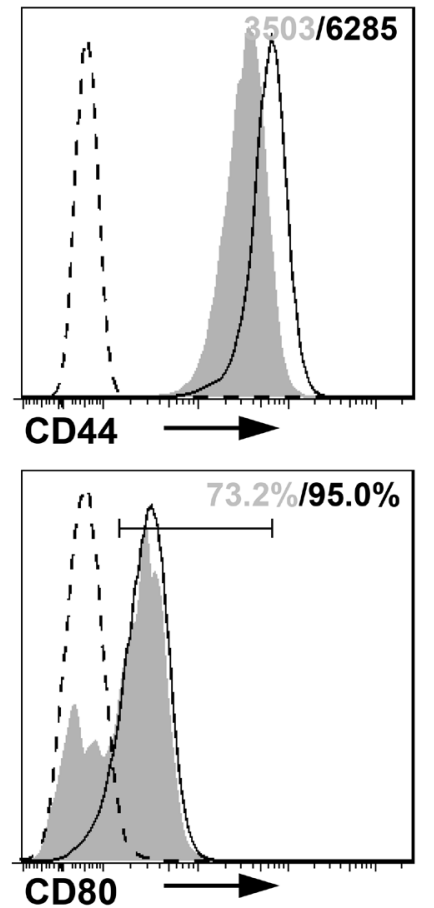

(B)

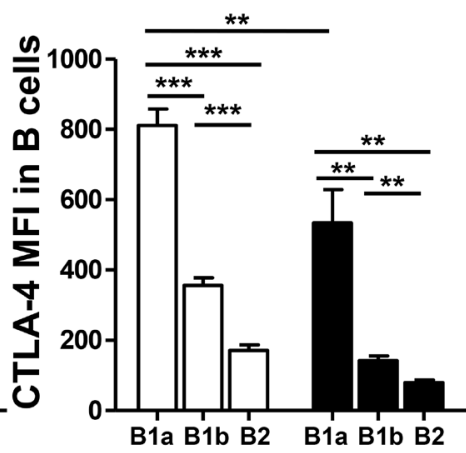

(C)

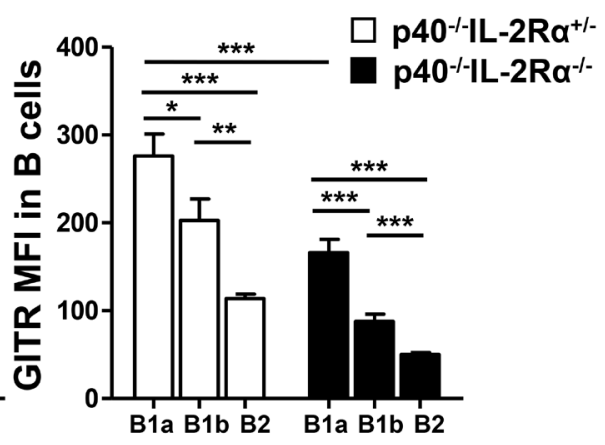

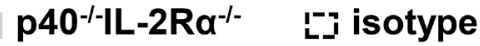
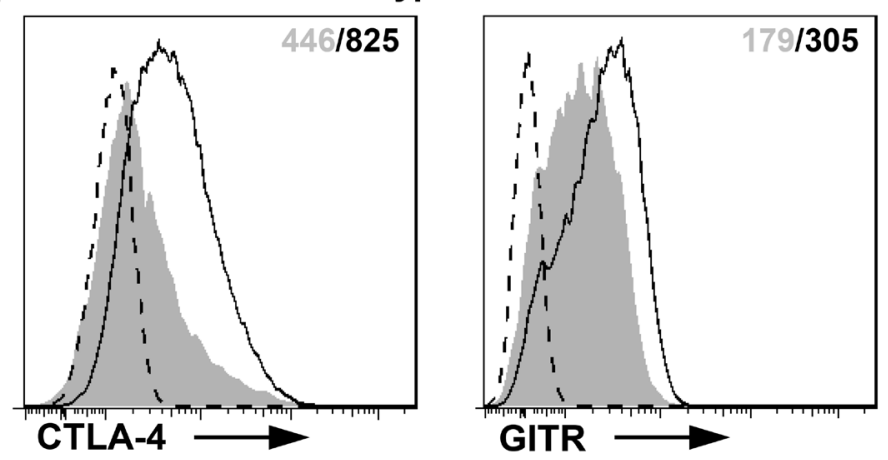

(F)

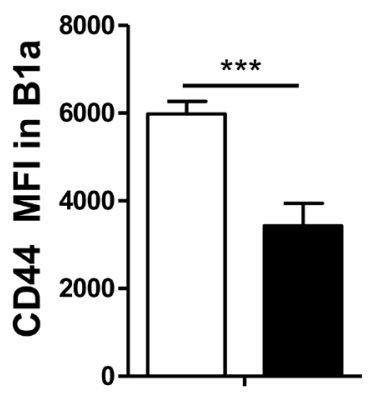

$\square \mathrm{p} 40^{--1} \mathrm{IL}-2 \mathrm{R} \alpha^{+/-}$

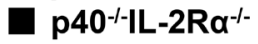

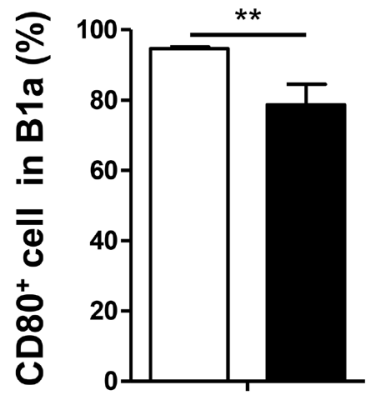

Figure 4: PC B cells from $p 40^{-} I L-2 R \alpha^{-/}$mice displayed reduced regulatory and less activated phenotype. Statistical analysis of frequency or mean fluorescence intensity (MFI) of regulatory molecules IL-10 A., CTLA-4 B. and GITR C. in PC B cell subsets from $p 40^{-} I L-2 R \alpha^{-\prec}$ mice $(n=7)$ and $p 40^{-}-I L-2 R \alpha^{+/}$mice $(n=4)$. D. Expression of regulatory molecules (IL-10, CTLA-4, GITR) in PC B1a cells from $p 40^{-} I L-2 R \alpha^{-\prec}$ mice $(n=7)$ and $p 40^{-} I L-2 R \alpha^{+/}$mice $(n=4)$. E. Expression of activation markers (CD44, CD80) in PC B1a cells from $p 40^{-} I L-2 R \alpha^{-/}$mice $(n=4)$ and $p 40^{-}-I L-2 R \alpha^{+/}$mice $(n=3)$. F. Statistical analysis of frequency or mean fluorescence intensity (MFI) of phenotypic markers shown in $\mathbf{E}$. . ${ }^{*} P<0.05,{ }^{*} P<0.01,{ }^{* * *} P<0.001$. 
(A)

p40 $0^{-1-C D 25^{+/-}}$p40--CD25 $5^{-1-}$

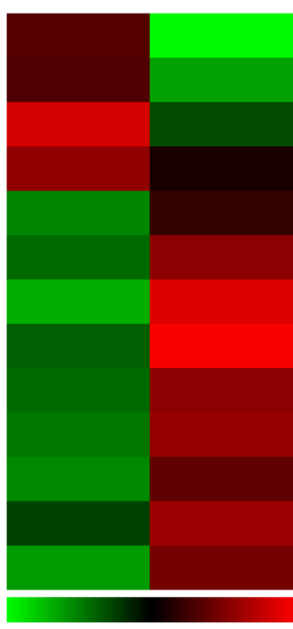

Cd44

Cd80

$\mathrm{Bc} / 6$

Ctla4

Pirb

Ahr

Btla

II21r

Ccr6

Cd72

Cd22

IcosI

Tbx21

(B) Functions legend Networks legend

Upregulated genes Physical interactions

Downregulated genes

Neighbour genes

Co-localization

Shared protein domains

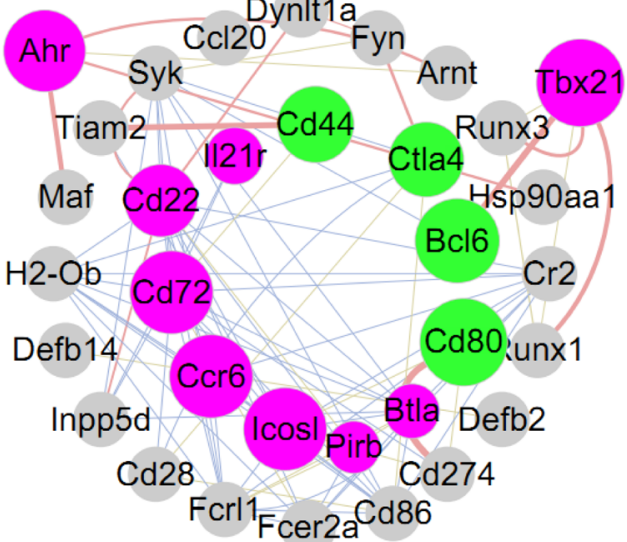

$\begin{array}{lll}-1.95 & 0 & 1.95\end{array}$

(C)

Cd44

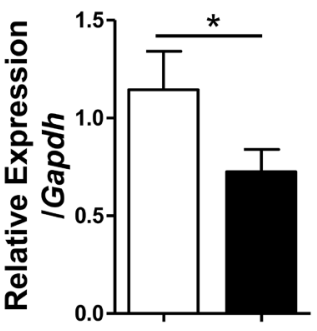

Pirb

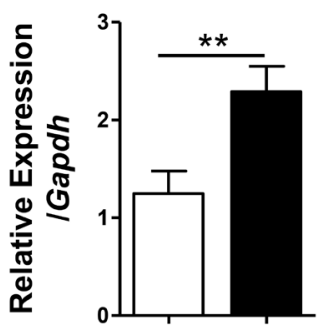

Cd72

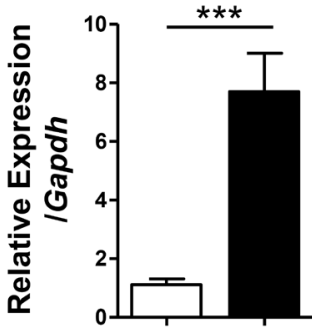

Cd80

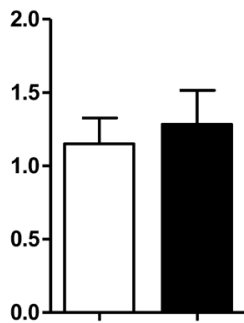

Ahr

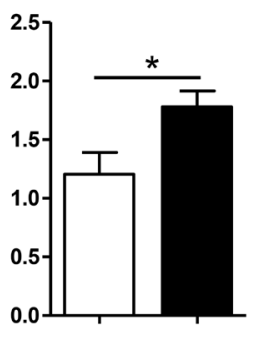

Cd22

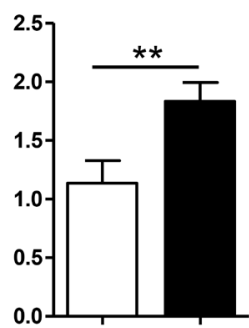

Bc/6

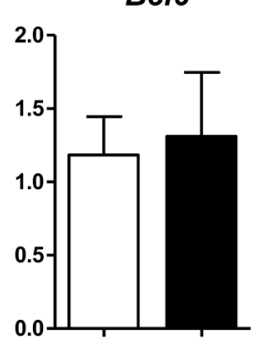

Btla

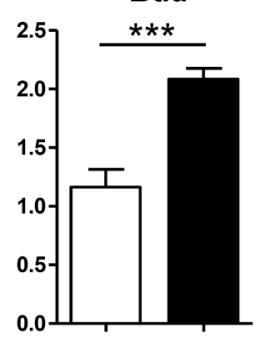

II10

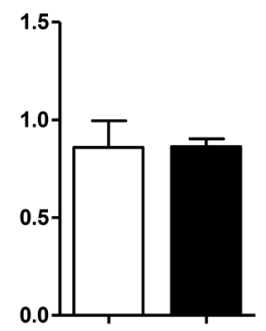

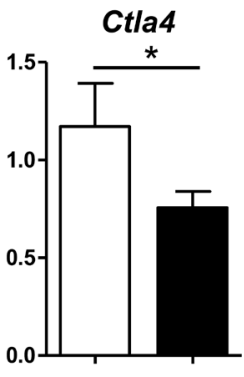

II21r

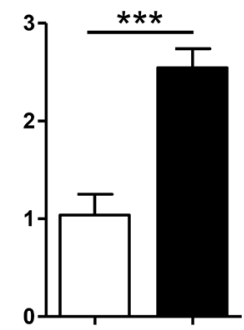

$\square$ p40-/IL-2Ra ${ }^{+/-}$

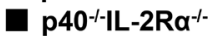

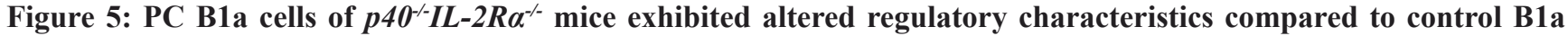
cells. A. A heat map of selected genes from the transcriptional array were studied as noted in black (not significantly altered), green (down-regulated in $p 40-I L-2 R \alpha^{-/}$mice) or red (up-regulated in $p 40^{-} I L-2 R \alpha^{-/}$mice). These genes were correlated with B cell function. B. Interaction network of these genes in A. and their first neighbor genes. Target genes were depicted as a circular node. Up-regulated genes are indicated in pink, while down-regulated genes are indicated in green of $p 40^{-} I L-2 R \alpha^{-}-$mice B1a cells. The size of the circular node of B cell function genes were determined by the level of gene expression. C. Quantitative PCR analysis comparing mRNA expression level of selected genes between $p 40^{-} I L-2 R \alpha^{-/}$and $p 40^{-} I L-2 R \alpha^{+/}$mice. ${ }^{*} P<0.05$, ${ }^{* *} P<0.01, * * * P<0.001$. 
5A). Moreover, the interaction network of these genes reflected that critical genes relevant to B cell function, including Cd274 (Pdl1), Cd28 and Cd86, were also closely related (Figure $5 \mathrm{~B}$ ). To confirm these data, we performed quantitative real-time PCR. We noted that $C d 44$ and Ctla 4 were down-regulated. The expression of Pirb, Ahr, Btla, Il21r, $C d 72$ and $C d 22$ were significantly up-regulated (Figure 5C). Thus the quantitative PCR results confirmed our transcriptional microarray analysis.

\section{DISCUSSION}

There has been significant attention on the role of $\mathrm{B}$ regulatory cells and loss of tolerance. In murine systems this has led to observations on peritoneal B1 cells [30, 34-36]. However, in humans, the role and definition of B1 cells is less clear and therefore the data herein on this murine model of autoimmune cholangitis is particularly relevant. Clearly B cell-related genes that impact function were altered with inflammation. For example, select molecules with ITIM domains such as BTLA, CD72 and CD22, were significantly increased as part of the inhibition of BCR signaling transduction. In contrast, some regulatory molecules, i.e. IL-10, were decreased because of the up-regulation of Ahr [37]. This discussion is also significant because of the relationship of the B1a cell cycle and the expression of Ki67 and its relationship to both qualitative and quantitative activity of B1a cells [38, 39]. Hence, our data herein reported the impairment of regulatory function and cell numbers of Bla cells in $p 40^{--} I L-2 R \alpha^{-/}$mice, and its augmentation of T cell production of IFN- $\gamma$ is significant (Figure 6).

Regulatory B cells are considered a new subset and have been shown to be integral to the maintenance of tolerance [40]. Indeed, B cells exert their regulatory role through the production of interleukin-10 (IL-10) by

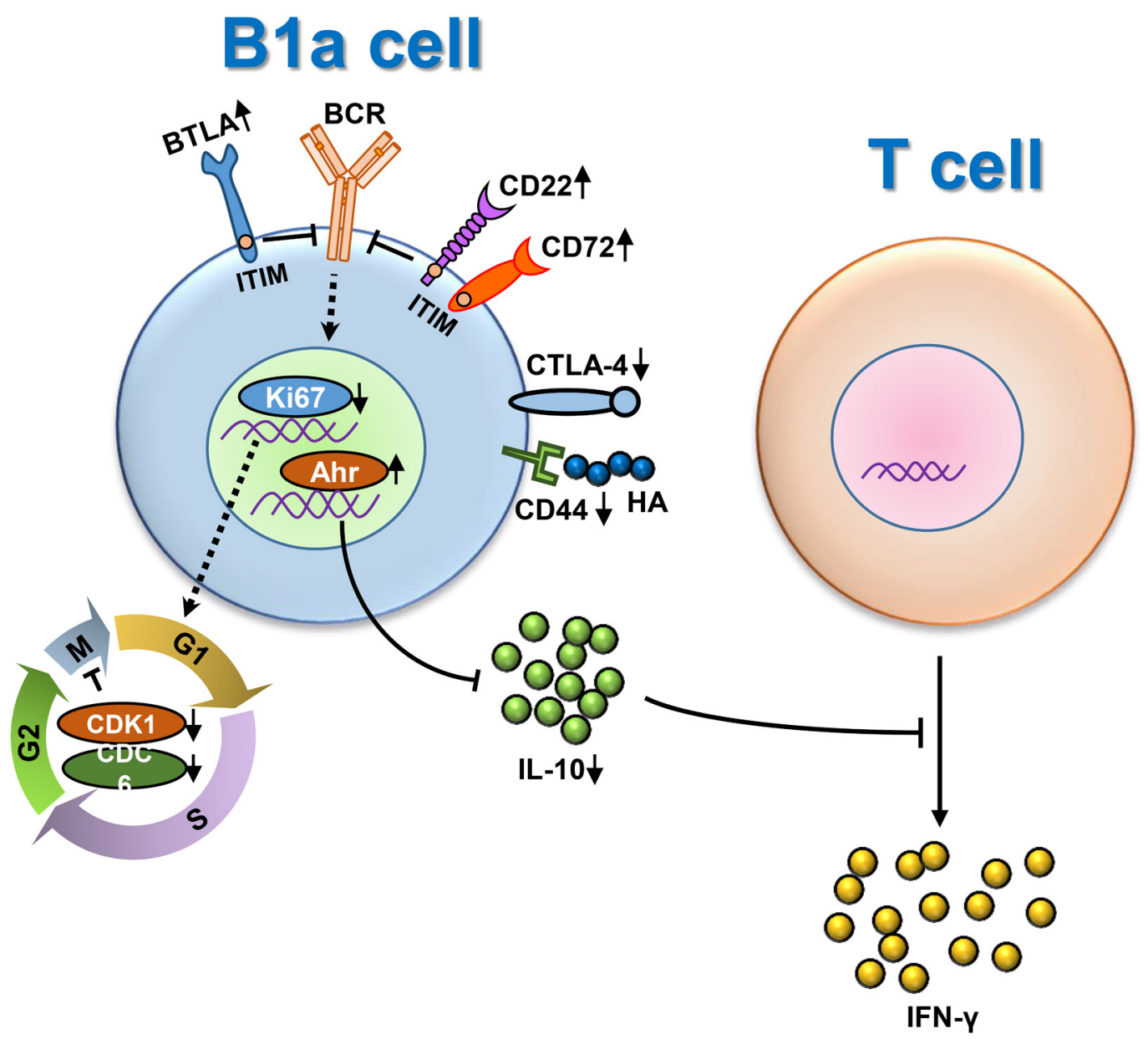

Figure 6: Dysregulation of peritoneal cavity B1a cells of $p 40^{-/-} I L-2 R \alpha^{-/}$mice under inflammatory scenario. On the one hand, some molecules with ITIM domains like BTLA, CD72 and CD22, were significantly increased to inhibit BCR signaling transduction. Meanwhile, the B1a cell cycle was delayed as the expression of Ki67 and other cell cycle related genes were decreased, leading to the reduced number of B1a cells. On the other hand, some regulatory molecules, e.g. IL-10, were significant decreased because of the upregulation of Ahr. Consequently, the regulatory function of Bla cells was impaired, leading to the augmentation of IFN- $\gamma$ secretion form T cells. 
either B1 cells, marginal zone (MZ) B cells, or other B cell subpopulations [41-44]. IL-10 mediates suppression of inflammation by several mechanisms, including restricting the production of proinflammatory cytokines, such as IFN- $\gamma$ and IL-17, downregulating the expression of MHC class II [40], and maintaining suppressive function of regulatory $\mathrm{T}$ cells [45]. Foxp $3^{+}$regulatory $\mathrm{T}$ cells derived IL-10 is important to restrain immune responses [46]. Foxp3- T cells with IL-10 expression, i.e. Tr1 cells, also have regulatory abilities [47]. However, the suppressive function of regulatory B cells is primarily mediated by IL10 [40] and thus the downregulated secretion of IL-10 by $\mathrm{B}$ la cells in the PC of $p 40^{--} I L-2 R \alpha^{--}$mice has additional implications.

CTLA-4, an activation-induced homodimeric glycoprotein receptor, is expressed on T cells and interacts with the CD80/CD86 ligands which are also expressed on the surface of APCs and T cells $[48,49]$. CTLA-4 acts as a negative regulator and functions to reduce $\mathrm{T}$ cell activation after B7 engagement, leading to down-regulation of T cell responses and to the preservation of $\mathrm{T}$ cell homeostasis and peripheral tolerance [50]. CTLA-4 is critical for the suppressive function of regulatory and conventional $\mathrm{CD}^{+}$ $\mathrm{T}$ cells in both thymus and periphery [51-53]. It has been reported that B cells can express CTLA-4 in human and mice $[54,55]$, and this expression can be induced by activated T cells [56]. However, there is no significant data on the expression or function of CTLA-4 on PC B1a, B1b and $\mathrm{B} 2$ cells.

In our work the production of IL-10 and expression CTLA-4 were higher in B1a cells than B1b and B2 cells, suggesting that B1 a cells may be regulatory B cells. In line with decreased $\mathrm{B}$ cell numbers, the immune regulatory function of PC B cells were impaired based on the expression of IL-10 and CTLA-4 in PC B cells in $p 40^{--} I L-$ $2 R \alpha^{-/}$mice. Hence, we hypothesized that in $p 40^{-/} I L-2 R \alpha^{-/-}$ mice, decreased number and function of regulatory B cells led to regulatory $\mathrm{T}$ cell dysregulation with subsequent increased inflammatory responses. B cell survival can be inhibited by $\mathrm{CD}^{+} \mathrm{T}$ cells [57], IFN- $\gamma$ [58] and perhaps IL$21[59,60]$. Therefore, an increase in Th1 and cytotoxic T cells in $p 40^{-/} I L-2 R \alpha^{-/-}$mice may contribute to the decrease of B1a cells.

CD22 is a B cell transmembrane adhesion molecule with ITIMs in its cytoplasmic domain, and a negative regulator of $\mathrm{B}$ cell activation in response to local microenvironment [31]. CD22 inhibits BCR signaling by recruiting SHP-1, a protein tyrosine phosphatase, which can interfere with BCR-associated protein tyrosine kinase activation [61]. CD72 is also a B cell co-receptor containing ITIMs and also is an inhibitory co-receptor regulating the $\mathrm{B}$ cell immune response [62]. $\mathrm{CD}^{-1-}$ mice demonstrate increased B1a cell frequency in PC [63]. It is interesting that CD22 engagement before BCR stimulation can trigger the phosphorylation of CD72 [64]. These two molecules may have a synergistic role in regulating B cell activation. In our microarray and RT-PCR data, these same two molecules were both upregulated. Hence, there was significant inhibition of B1a cell activation in the PCs of $p 40^{-/} I L-2 R \alpha^{-/-}$mice.

Under normal circumstances, IL-2R $\alpha$ is expressed on regulatory and activated $\mathrm{T}$ cells; most lymphoid cells do not express IL-2R $\alpha$ when directly examined ex vivo [65]. However, mature B cells can also express IL-2R $\alpha$. In mice, IL-2R $\alpha$ can be expressed on $\mathrm{B}$ cells from PC [66]. Interestingly, murine $\mathrm{CD} 25^{+} \mathrm{B}$ cells have a higher expression of CD5, CD122 and CD132, suggesting that $\mathrm{CD} 25^{+} \mathrm{B}$ cells are $\mathrm{B} 1 \mathrm{a}$ cells and can respond to IL2. Murine $\mathrm{CD} 25^{+} \mathrm{B}$ cells, compared to humans, have a greater potential to secrete higher levels of IL-10 [67]. $\mathrm{CD} 25^{+} \mathrm{B}$ cells are detectable in humans and have more antigen-presenting ability than $\mathrm{CD}^{-} 5^{-} \mathrm{B}$ cells [68, 69]. CD25 can be upregulated in $\mathrm{CD}_{2} 5^{+} \mathrm{B}$ cells by Tolllike receptors, CD40 activation and IL-4 [68, 70]. In human, CD $19^{+} \mathrm{CD} 25^{\text {high }} \mathrm{B}$ cells appear to function as immunoregulatory cells and are a source of inhibitory cytokines, including IL-10 and TGF- $\beta$ [71]. However, it is not clear whether changes of $\mathrm{B}$ cell phenotype are due to an intrinsic deficiency of $I L-2 R \alpha$ or secondary to extrinsic factors such as an inflammatory microenvironment. We suggest that in the murine model herein, it is the microenvironment that leads to the dysregulation of PC $\mathrm{B} 1 \mathrm{a}$ cells and therefore impairs their function, leading to a cascade and feedback loop which will further exacerbate pathology.

\section{MATERIALS AND METHODS}

\section{Mice}

$I L-2 R \alpha^{-/}\left(B 6.129 S 4-I l 2 r a^{t m 1 D w}\right)$ and $p 40^{-/-}(B 6.129 S 1-$ $\left.I l 12 b^{t m I J m}\right)$ mice on a C57BL/6J background were initially obtained from The Jackson Laboratory (Bar Harbor, ME). $I L-2 R \alpha^{+/-}$mice were crossed with $p 40^{-/-}$mice to generate $p 40^{+/-} I L-2 R \alpha^{+/}$mice, then backcrossed with $p 40^{-/-}$mice to generate $p 40^{-/-} I L-2 R \alpha^{+/-}$mice as breeding pairs. $I L-2 R \alpha^{+-}$ mice were used as breeding pairs to generate $I L-2 R \alpha^{+/-}$ mice. We initially compared $p 40^{-/} I L-2 R \alpha^{+/-}$mice to $I L$ $2 R \alpha^{+/}$and control C57BL/6 (WT) mice and demonstrated that these strains were similar and healthy. Hence, $p 40^{-/} I L$ $2 R \alpha^{+/}$mice were used as controls throughout these studies. All mice were studied at 3-18 weeks and serially studied at $3,6,9,12$ and 18 weeks of age, with a minimum of 3 mice at each data point. Microarray and Real Time PCR assays were performed in 7-week old female mice. $d n T G F \beta R I I$ (B6.Cg- $T g(C d 4-T G F B R 2) 16 F l v / J)$ mice, abbreviated as TG and used as another PBC mouse model [72], were obtained from the University of California at Davis, and 
studied at 12 weeks of age with littermate WT mice. All assays were performed in triplicate and each experiment replicated twice. All mice were maintained in individually ventilated cages under specific pathogen-free conditions at the Laboratory Animal Center, School of Life Sciences, University of Science and Technology of China. Animal experiments conformed to the guidelines outlined in the Guide for the Care and Use of Laboratory Animals by the Laboratory Animal Center, School of Life Sciences, University of Science and Technology of China.

\section{Liver histology}

Liver tissues were excised and immediately fixed with $10 \%$ buffered formalin solution for 2 days at room temperature, then embedded in paraffin and cut into 4 $\mu \mathrm{m}$ sections for hematoxylin-eosin (H\&E) staining [73]. Images were then obtained using an upright microscope (Axioskop 2 plus, Carl Zeiss, Oberkochen, Germany) in high-power fields $(10 \times 40)$.

\section{Isolation of hepatic and splenic mononuclear cells (MNCs) and peritoneal cavity cells}

As previously outlined [74], we isolated hepatic MNCs as follows. Firstly, livers were disrupted using a syringe handle, suspended in $\mathrm{PBS} / 0.2 \% \mathrm{BSA}$, and passed through a steel mesh. After centrifugation at $85 \mathrm{~g}$ for one minute to remove the hepatocyte pellets, the residual cells were collected. MNCs from suspended liver cells were then isolated by centrifugation with $40 \%$ and 70\% Percoll (GE Healthcare, Little Chalfont, United Kingdom) at $805 \mathrm{~g}$ for 20 minutes, and cells at the interface were collected. Spleen was disrupted between two glass slides and red blood cells were lysed for $10 \mathrm{~min}$. After neutralizing and centrifugation, pellets were resuspended with PBS. For peritoneal cavity cell isolation, the outer skin of the peritoneum was gently pulled back to expose the inner skin lining the peritoneal cavity. A needle was carefully inserted into the peritoneum to avoid puncture of organs [75]. $8 \mathrm{ml}$ of ice cold PBS (with 2\% BSA) was injected into the peritoneal cavity and washed repeatedly using a $10 \mathrm{ml}$ syringe. The collected cell suspension was centrifuged at $453 \mathrm{~g}$ for 5 minutes, the supernatant discarded and resuspended in media or PBS. Single cell suspensions were washed and counted. Viability of cells was confirmed by trypan blue exclusion.

\section{Collection of peritoneal cavity lavage fluid}

A syringe containing $100 \mathrm{ul}$ ice cold PBS, with a $29 \mathrm{G}(0.33 \mathrm{~mm})$ needle was carefully inserted into the peritoneum to avoid puncture of organs. After injection, the peritoneum was gently massaged for 2 minutes to dislodge any attached cells into the PBS solution. Thence an incision was made into the peritoneum and fluid collected with a Pasteur pipette; the fluid was then centrifuged at $5500 \mathrm{~g}$ for 5 minutes and supernatant assayed using a cytometric bead assay (CBA) [10].

\section{Flow cytometry}

$1 \times 10^{6}$ cell preparations were incubated with purified anti-CD16/CD32 antibody (BioLegend, San Diego, CA) for 15 minutes at $4^{\circ} \mathrm{C}$. Cells were stained for 20 minutes at $4^{\circ} \mathrm{C}$ with cocktails containing combinations of fluorochrome-conjugated monoclonal antibodies for cell surface markers including Pacific Blue-CD3, Pacific BluePDCA-1, FITC-B220, APC/Cy7-CD4, APC/Cy7-IgD, APC/Cy7-CD19, PE/Cy7-NK1.1, PE/Cy7-CD23, PerCP/ Cy5.5-IgM, APC-CD21/35, Alexa Fluor 647-CD11b, PE-F4/80, PE-CD5 (BioLegend), V500-CD4 and V500CD8a (BD Biosciences, San Diego, CA). In PC, B cells were defined as $\mathrm{CD}^{+} 9^{+} \mathrm{CD}^{-}$. Gated on B cells, B1a cells were defined as $\mathrm{CD} 11 \mathrm{~b}^{+} \mathrm{CD}^{+}$and $\mathrm{B} 1 \mathrm{~b}$ cells were

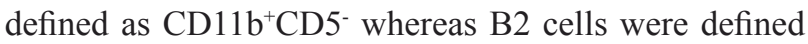
as $\mathrm{CD} 11 \mathrm{~b}^{-C D} 5^{-}$[76]. In spleen, B cells were defined as B220 ${ }^{+}$CD3-PDCA-1 ${ }^{-}$. Gated on B cells, B1a cells were defined as $\mathrm{CD}^{2} 3^{-} \mathrm{CD}^{+}{ }^{+} \mathrm{IgM}^{\mathrm{hi}} \operatorname{IgD}^{\text {lo }}$ and $\mathrm{B} 1 \mathrm{~b}$ cells were defined as $\mathrm{CD}^{-}{ }^{-} \mathrm{CD}^{-}{ }^{-} \mathrm{IgM}^{\mathrm{hi}} \mathrm{IgD}^{\mathrm{lo}} \mathrm{CD} 21 / 35^{-}$, whereas B2 cells, contained Follicular $\mathrm{B}$ cells $\left(\mathrm{CD} 21 / 35^{\mathrm{lo}} \mathrm{CD} 23^{+}\right)$ and Marginal zone B cells (CD21/35 hi CD23-) [17]. The numbers of each cell subsets were calculated based on flow cytometric analysis of stained cells with specific fluorochrome-conjugated antibodies [77].

For intracellular cytokine staining, cells were suspended in RPMI-1640 with 10\% fetal bovine serum (FBS) and stimulated with Cell Stimulation Cocktail (plus protein transport inhibitors) (eBioscience) at $37^{\circ} \mathrm{C}$ for 4 hours. Cells were incubated with purified anti-CD16/ CD32 antibody and then stained with Pacific BlueCD3, APC/Cy7-CD4, PerCP/Cy5.5-CD19, Alexa Fluor 647-CD11b, FITC-CD5, PE/Cy7-CD11b and PE/Cy7NK1.1 (BioLegend), V500-CD8a (BD Biosciences) as above, fixed with fixation buffer, and permeabilized with permeabilization wash buffer (BioLegend); cells were thereafter stained for intracellular PE-IFN- $\gamma$, PE-IL-10, APC-IL-10, or PE-CTLA-4 (BioLegend). Normal IgG isotype controls (BioLegend) were used in parallel [78]. Intracellular Ki67 was identified by PE-Ki67 (BioLegend) using a Foxp3 staining kit (eBioscience).

Detection of apoptosis using a combined Annexin $\mathrm{V}$ and 7 -AAD assay. $1 \times 10^{6}$ cells were incubated with purified anti-CD16/CD32 antibody and then stained with FITC-CD4, PE-CD5, APC/Cy7-CD19 (BioLegend), and $\mathrm{PE} / \mathrm{Cy} 7-\mathrm{CD} 11 \mathrm{~b}$. The washed cells were resuspended in Annexin $\mathrm{V}$ binding buffer (BioLegend), and stained with Alexa Fluor 647-Annexin V (BioLegend) and 7-AAD (BioLegend) at room temperature for $15 \mathrm{~min}$. Early stage apoptotic cells were defined as Annexin $\mathrm{V}^{+} 7-\mathrm{AAD}^{-}$and 
Table 2: Real Time PCR primers used in this work.

\begin{tabular}{|l|l|l|}
\hline \hline Genes & Forward primer $\mathbf{5}^{\prime} \mathbf{- 3}$, & Reverse primer $\mathbf{5}^{\prime} \mathbf{- 3}$ \\
\hline$C d 44$ & TCGATTTGAATGTAACCTGCCG & CAGTCCGGGAGATACTGTAGC \\
\hline$C d 80$ & ACCCCCAACATAACTGAGTCT & TTCCAACCAAGAGAAGCGAGG \\
\hline$B c l 6$ & CCGGCACGCTAGTGATGTT & TGTCTTATGGGCTCTAAACTGCT \\
\hline Ctla 4 & TTTTGTAGCCCTGCTCACTCT & CTGAAGGTTGGGTCACCTGTA \\
\hline Pirb & GACTTATGCCCAGGTGAAACC & AGATTCGGCAGCCTGATTGTT \\
\hline Ahr & AGCCGGTGCAGAAAACAGTAA & AGGCGGTCTAACTCTGTGTTC \\
\hline Btla & TGCTTGGGACTCCTCGGTTAT & ACACAGATTGTCCATTGTGCT \\
\hline$I l 21 r$ & GGCTGCCTTACTCCTGCTG & TCATCTTGCCAGGTGAGACTG \\
\hline$C d 72$ & ATGGCTGACGCTATCACGTAT & CCTGTCCTAGATGGTTAGATGCG \\
\hline$C d 22$ & ATGCGCGTCCATTACCTGTG & TCAACGGTCCAATCATTTGCT \\
\hline$I l 10$ & GCCAGAGCCACATGCTCCTA & GATAAGGCTTGGCAACCCAAGTAA \\
\hline
\end{tabular}

late stage apoptotic cells were defined as Annexin $\mathrm{V}^{+} 7$ $\mathrm{AAD}^{+}$. FACSVerse flow cytometry (BD Immunocytometry Systems, San Jose, CA) was used to acquire data, which was analyzed by Flowjo software (Tree star, Inc., Ashland, OR).

\section{Gene-expression profiling analysis of peritoneal cavity B1a cells}

PC B1a cells from 7-week old female $p 40^{-/} I L$ $2 R \alpha^{-/-}$and $p 40^{-/-} I L-2 R \alpha^{+/-}$mice were isolated as above; the sorting purity was greater than $96 \%$. Cells were suspended in TRIzol and total RNA extracted with an RNeasy Mini Kit (Qiagen, Hilden, Germany) and hybridized to Agilent chips. Fluorescence was detected using the Agilent Scanner G2505C (Agilent Technologies) and images were analyzed using Feature Extraction software (version 10.7.1.1, Agilent Technologies). A transcription profile chip service was provided by Shanghai OE Biotechnology Cooperation (Shanghai, China). Expression fluorescence values were $\log _{2}$-transformed, and subsequently analyzed using Genespring. Differentially expressed genes were defined as equal to or more than 2 fold differences between the two groups; signal values were confirmed beyond background signals, and the genes were classified based on the annotation of the Gene Ontology (GO) project. Volcano plot, heat map and red-green scale schemes were designed using Multiple Experiment Viewer 4.8 software. The microarray data was deposited on the National Center for Biotechnology Information GEO repository under accession number GSE79190.

\section{Prediction of target genes and the establishment of interaction networks}

The target genes for all selected B cell functional genes were identified or predicted using three online bioinformatic databases, including GeneMANIA (http:// www.genemania.org), STRING (http://string-db.org) and Gene Network Central (http://www.sabiosciences.com) [79]. The open source Bioinformatics software Cytoscape 3.2.1 (http://www.cytoscape.org) was used to create the interaction networks.

\section{Cytokines in PC lavage fluid}

The levels of IFN- $\gamma$, TNF- $\alpha$, IL-6, MCP-1 and IL-10 from PC lavage fluid were measured with a BD cytometric bead assay (CBA) "Mouse inflammation" kit (BD Pharmingen), using a BD FACSVerse flow cytometer with CBA software.

\section{Correlation analysis}

Correlation analysis was made using GraphPad Prism 5 with linear regression analysis. The linear correlation index $\mathrm{r}^{2}$ and $\mathrm{P}$ values were calculated.

\section{Real time PCR}

B1a peritoneal isolated cells were isolated from

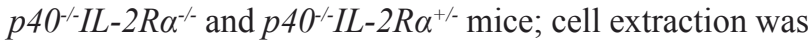
performed using Trizol Reagent (Invitrogen, Carlsbad, CA), and cDNA synthesized with the PrimeScript ${ }^{\mathbb{B}}$ RT reagent Kit (Takara). Quantitative real-time PCR was performed by AB Stepone real-time PCR system (Applied Biosystems, Carlsbad, CA) and using SYBR ${ }^{\circledR}$ Premix Ex TaqTM II (Takara). The primers used were noted in Table 2 and based on PrimerBank and confirmed using NCBI primer blast. The expression levels of target genes were normalized to the housekeeping gene Gapdh $(\Delta \mathrm{Ct})$. The results were calculated by the $2^{-\Delta \Delta \mathrm{Ct}}$ method. 


\section{Statistical analysis}

Statistical significance was analyzed using GraphPad Prism 5 (GraphPad Software, San Diego, CA). All experiments were replicated at least three times with similar results. All data are expressed as mean \pm standard deviation (SD), and evaluated using a 2-tailed unpaired Student $\mathrm{t}$ test.

\section{CONFLICTS OF INTEREST}

The authors have declared that no conflict of interest exists.

\section{GRANT SUPPORT}

Financial support provided by the National Basic Research Program of China (973 Program2013CB944900), the National Natural Science Foundation of China (81130058, 81430034, 91542123, 81401336) and the Research Fund for the Doctoral Program of Higher Education of China (RFDP 20133402110015).

\section{REFERENCES}

1. Beuers $U$ and Gershwin ME. Unmet challenges in immune-mediated hepatobiliary diseases. Clin Rev Allergy Immunol. 2015; 48:127-131.

2. Gershwin ME, Mackay IR, Sturgess A and Coppel RL. Identification and specificity of a cDNA encoding the 70 $\mathrm{kd}$ mitochondrial antigen recognized in primary biliary cirrhosis. J Immunol. 1987; 138:3525-3531.

3. Kaplan MM and Gershwin ME. Primary biliary cirrhosis. $\mathrm{N}$ Engl J Med. 2005; 353:1261-1273.

4. Li Y, Wang W, Tang L, He X, Yan X, Zhang X, Zhu Y, Sun J, Shi Y, Ma X, Mackay IR, Gershwin ME, Han Y and Hou J. Chemokine (C-X-C motif) ligand 13 promotes intrahepatic chemokine (C-X-C motif) receptor 5+ lymphocyte homing and aberrant B-cell immune responses in primary biliary cirrhosis. Hepatology. 2015; 61:19982007.

5. Shimoda S, Hisamoto S, Harada K, Iwasaka S, Chong Y, Nakamura M, Bekki Y, Yoshizumi T, Shirabe K, Ikegami T, Maehara Y, He XS, Gershwin ME and Akashi K. Natural killer cells regulate $\mathrm{T}$ cell immune responses in primary biliary cirrhosis. Hepatology. 2015; 62:1817-1827.

6. Wang L, Sun Y, Zhang Z, Jia Y, Zou Z, Ding J, Li Y, Xu X, Jin L, Yang T, Li Z, Sun Y, Zhang JY, Lv S, Chen L, Li $\mathrm{B}$, et al. CXCR5+ CD4+ T follicular helper cells participate in the pathogenesis of primary biliary cirrhosis. Hepatology. 2015; 61:627-638.

7. Zhang J, Zhang W, Leung PS, Bowlus CL, Dhaliwal S, Coppel RL, Ansari AA, Yang GX, Wang J, Kenny TP, He XS, Mackay IR and Gershwin ME. Ongoing activation of autoantigen-specific B cells in primary biliary cirrhosis. Hepatology. 2014; 60:1708-1716.

8. Huang W, Kachapati K, Adams D, Wu Y, Leung PS, Yang GX, Zhang W, Ansari AA, Flavell RA, Gershwin ME and Ridgway WM. Murine autoimmune cholangitis requires two hits: cytotoxic KLRG1(+) CD8 effector cells and defective T regulatory cells. J Autoimmun. 2014; 50:123134.

9. Tanaka H, Yang GX, Tomiyama T, Tsuneyama K, Zhang W, Leung PS, Coppel RL, Joh T, Nadler SG, Ansari AA, Bowlus $\mathrm{C}$ and Gershwin ME. Immunological potential of cytotoxic $\mathrm{T}$ lymphocyte antigen 4 immunoglobulin in murine autoimmune cholangitis. Clin Exp Immunol. 2015; 180:371-382.

10. Wang YH, Yang W, Yang JB, Jia YJ, Tang W, Gershwin ME, Ridgway WM and Lian ZX. Systems biologic analysis of $\mathrm{T}$ regulatory cells genetic pathways in murine primary biliary cirrhosis. Journal of autoimmunity. 2015; 59:26-37.

11. Yang JB, Wang YH, Yang W, Lu FT, Ma HD, Zhao ZB, Jia YJ, Tang W, Tsuneyama K, Ridgway WM, Gershwin ME and Lian ZX. Successful treatment of murine autoimmune cholangitis by parabiosis: Implications for hematopoietic therapy. J Autoimmun. 2016; 66:108-117.

12. Yao Y, Yang W, Yang YQ, Ma HD, Lu FT, Li L, Tao YY, Tsuneyama K, Zhang W, Friedman S, Gershwin ME and Lian ZX. Distinct from its canonical effects, deletion of IL-12p40 induces cholangitis and fibrosis in interleukin2Ralpha(-/-) mice. Journal of autoimmunity. 2014; 51:99108.

13. Moritoki Y, Tsuda M, Tsuneyama K, Zhang W, Yoshida K, Lian ZX, Yang GX, Ridgway WM, Wicker LS, Ansari AA and Gershwin ME. B cells promote hepatic inflammation, biliary cyst formation, and salivary gland inflammation in the NOD.c3c4 model of autoimmune cholangitis. Cellular immunology. 2011; 268:16-23.

14. Moritoki Y, Lian ZX, Lindor K, Tuscano J, Tsuneyama K, Zhang W, Ueno Y, Dunn R, Kehry M, Coppel RL, Mackay IR and Gershwin ME. B-cell depletion with anti-CD20 ameliorates autoimmune cholangitis but exacerbates colitis in transforming growth factor-beta receptor II dominant negative mice. Hepatology. 2009; 50:1893-1903.

15. Moritoki Y, Zhang W, Tsuneyama K, Yoshida K, Wakabayashi K, Yang GX, Bowlus C, Ridgway WM, Ueno Y, Ansari AA, Coppel RL, Mackay IR, Flavell RA, Gershwin ME and Lian ZX. B cells suppress the inflammatory response in a mouse model of primary biliary cirrhosis. Gastroenterology. 2009; 136:1037-1047.

16. Dhirapong A, Lleo A, Yang GX, Tsuneyama K, Dunn R, Kehry M, Packard TA, Cambier JC, Liu FT, Lindor K, Coppel RL, Ansari AA and Gershwin ME. B cell depletion therapy exacerbates murine primary biliary cirrhosis. Hepatology. 2011; 53:527-535.

17. Baumgarth $\mathrm{N}$. The double life of a B-1 cell: self-reactivity selects for protective effector functions. Nature reviews Immunology. 2011; 11:34-46. 
18. LeBien TW and Tedder TF. B lymphocytes: how they develop and function. Blood. 2008; 112:1570-1580.

19. Rosser EC and Mauri C. Regulatory B cells: origin, phenotype, and function. Immunity. 2015; 42:607-612.

20. Mizoguchi A and Bhan AK. A case for regulatory B cells. Journal of immunology. 2006; 176:705-710.

21. Yang M, Rui K, Wang S and Lu L. Regulatory B cells in autoimmune diseases. Cellular \& molecular immunology. 2013; 10:122-132.

22. Maseda D, Candando KM, Smith SH, Kalampokis I, Weaver CT, Plevy SE, Poe JC and Tedder TF. Peritoneal cavity regulatory $\mathrm{B}$ cells (B10 cells) modulate IFNgamma+CD4+ T cell numbers during colitis development in mice. Journal of immunology. 2013; 191:2780-2795.

23. Shen P, Roch T, Lampropoulou V, O'Connor RA, Stervbo U, Hilgenberg E, Ries S, Dang VD, Jaimes Y, Daridon C, Li R, Jouneau L, Boudinot P, Wilantri S, Sakwa I, Miyazaki $\mathrm{Y}$, et al. IL-35-producing B cells are critical regulators of immunity during autoimmune and infectious diseases. Nature. 2014; 507:366-370.

24. Liu X, Jiang X, Liu R, Wang L, Qian T, Zheng Y, Deng Y, Huang E, Xu F, Wang JY and Chu Y. B cells expressing CD11b effectively inhibit CD4+ T-cell responses and ameliorate experimental autoimmune hepatitis in mice. Hepatology. 2015; 62:1563-1575.

25. Baumgarth N, Herman OC, Jager GC, Brown LE, Herzenberg LA and Chen J. B-1 and B-2 cell-derived immunoglobulin $\mathrm{M}$ antibodies are nonredundant components of the protective response to influenza virus infection. The Journal of experimental medicine. 2000; 192:271-280

26. Boes M, Prodeus AP, Schmidt T, Carroll MC and Chen J. A critical role of natural immunoglobulin $\mathrm{M}$ in immediate defense against systemic bacterial infection. The Journal of experimental medicine. 1998; 188:2381-2386.

27. Tumang JR, Holodick NE, Vizconde TC, Kaku H, Frances $\mathrm{R}$ and Rothstein TL. A CD25(-) positive population of activated B1 cells expresses LIFR and responds to LIF. Frontiers in immunology. 2011; 2:6.

28. Zhang X. Regulatory functions of innate-like B cells. Cellular and Molecular Immunology. 2013; 10:113-121.

29. Wang H, Shin DM, Abbasi S, Jain S, Kovalchuk AL, Beaty N, Chen S, Gonzalez-Garcia I and Morse HC, 3rd. Expression of plasma cell alloantigen 1 defines layered development of B-1a B-cell subsets with distinct innatelike functions. Proceedings of the National Academy of Sciences of the United States of America. 2012; 109:2007720082.

30. Margry B, Kersemakers SC, Hoek A, Arkesteijn GJ, Wieland WH, van Eden $\mathrm{W}$ and Broere F. Activated peritoneal cavity B-1a cells possess regulatory B cell properties. PloS one. 2014; 9:e88869.

31. Nakashima H, Hamaguchi $Y$, Watanabe R, Ishiura N,
Kuwano Y, Okochi H, Takahashi Y, Tamaki K, Sato S, Tedder TF and Fujimoto M. CD22 expression mediates the regulatory functions of peritoneal B-1a cells during the remission phase of contact hypersensitivity reactions. Journal of immunology. 2010; 184:4637-4645.

32. Klinker MW and Lundy SK. Multiple mechanisms of immune suppression by B lymphocytes. Molecular medicine. 2012; 18:123-137.

33. DiLillo DJ, Matsushita T and Tedder TF. B10 cells and regulatory $\mathrm{B}$ cells balance immune responses during inflammation, autoimmunity, and cancer. Annals of the New York Academy of Sciences. 2010; 1183:38-57.

34. Shimomura Y, Mizoguchi E, Sugimoto K, Kibe R, Benno Y, Mizoguchi A and Bhan AK. Regulatory role of B-1 B cells in chronic colitis. International immunology. 2008; 20:729-737.

35. Zhang X. Regulatory functions of innate-like B cells. Cellular \& molecular immunology. 2013; 10:113-121.

36. Hsu LH, Li KP, Chu KH and Chiang BL. A B-1a cell subset induces Foxp3(-) T cells with regulatory activity through an IL-10-independent pathway. Cellular \& molecular immunology. 2015; 12:354-365.

37. Piper C, Bending D, Varsani H, Arnold K, Wedderburn L, Mauri C and Nistala K. Regulatory B cell Il-10 production is diminished in juvenile dermatomyositis. Pediatric Rheumatology. 2014; 12:P86.

38. Li ZM, Huang JJ, Xia Y, Zhu YJ, Zhao W, Wei WX, Jiang WQ, Lin TY, Huang HQ and Guan ZZ. High Ki-67 expression in diffuse large B-cell lymphoma patients with non-germinal center subtype indicates limited survival benefit from R-CHOP therapy. European journal of haematology. 2012; 88:510-517.

39. Richards S, Watanabe C, Santos L, Craxton A and Clark EA. Regulation of B-cell entry into the cell cycle. Immunological reviews. 2008; 224:183-200.

40. Mauri $\mathrm{C}$ and Bosma $\mathrm{A}$. Immune regulatory function of $\mathrm{B}$ cells. Annual review of immunology. 2012; 30:221-241.

41. Bouaziz JD, Yanaba K and Tedder TF. Regulatory B cells as inhibitors of immune responses and inflammation. Immunological reviews. 2008; 224:201-214.

42. O'Garra A, Chang R, Go N, Hastings R, Haughton G and Howard M. Ly-1 B (B-1) cells are the main source of B cellderived interleukin 10. European journal of immunology. 1992; 22:711-717.

43. Candando KM, Lykken JM and Tedder TF. B10 cell regulation of health and disease. Immunological reviews. 2014; 259:259-272.

44. Matsumoto M, Baba A, Yokota T, Nishikawa H, Ohkawa Y, Kayama H, Kallies A, Nutt SL, Sakaguchi S, Takeda $\mathrm{K}$, Kurosaki $\mathrm{T}$ and Baba Y. Interleukin-10-producing plasmablasts exert regulatory function in autoimmune inflammation. Immunity. 2014; 41:1040-1051. 
45. Murai M, Turovskaya O, Kim G, Madan R, Karp CL, Cheroutre $\mathrm{H}$ and Kronenberg $\mathrm{M}$. Interleukin 10 acts on regulatory $\mathrm{T}$ cells to maintain expression of the transcription factor Foxp3 and suppressive function in mice with colitis. Nature immunology. 2009; 10:1178-1184.

46. Rubtsov YP, Rasmussen JP, Chi EY, Fontenot J, Castelli L, Ye X, Treuting P, Siewe L, Roers A, Henderson WR, Jr., Muller W and Rudensky AY. Regulatory T cell-derived interleukin-10 limits inflammation at environmental interfaces. Immunity. 2008; 28:546-558.

47. Ouyang W, Rutz S, Crellin NK, Valdez PA and Hymowitz SG. Regulation and functions of the IL-10 family of cytokines in inflammation and disease. Annual review of immunology. 2011; 29:71-109.

48. Linsley PS, Brady W, Urnes M, Grosmaire LS, Damle NK and Ledbetter JA. CTLA-4 is a second receptor for the B cell activation antigen B7. The Journal of experimental medicine. 1991; 174:561-569.

49. Chen YS and Shen CR. Immune checkpoint blockade therapy: the 2014 Tang Prize in Biopharmaceutical Science. Biomedical journal. 2015; 38:5-8.

50. Teft WA, Kirchhof MG and Madrenas J. A molecular perspective of CTLA-4 function. Annual review of immunology. 2006; 24:65-97.

51. Tai X, Van Laethem F, Pobezinsky L, Guinter T, Sharrow SO, Adams A, Granger L, Kruhlak M, Lindsten T, Thompson CB, Feigenbaum L and Singer A. Basis of CTLA-4 function in regulatory and conventional CD4(+) T cells. Blood. 2012; 119:5155-5163.

52. Verhagen J, Genolet R, Britton GJ, Stevenson BJ, SabatosPeyton CA, Dyson J, Luescher IF and Wraith DC. CTLA4 controls the thymic development of both conventional and regulatory $\mathrm{T}$ cells through modulation of the TCR repertoire. Proceedings of the National Academy of Sciences of the United States of America. 2013; 110:E221230.

53. Peggs KS, Quezada SA, Chambers CA, Korman AJ and Allison JP. Blockade of CTLA-4 on both effector and regulatory $\mathrm{T}$ cell compartments contributes to the antitumor activity of anti-CTLA-4 antibodies. The Journal of experimental medicine. 2009; 206:1717-1725.

54. Quandt D, Hoff H, Rudolph M, Fillatreau S and BrunnerWeinzierl MC. A new role of CTLA-4 on B cells in thymus-dependent immune responses in vivo. Journal of immunology. 2007; 179:7316-7324.

55. Steiner K, Moosig F, Csernok E, Selleng K, Gross WL, Fleischer $\mathrm{B}$ and Broker BM. Increased expression of CTLA-4 (CD152) by T and B lymphocytes in Wegener's granulomatosis. Clinical and experimental immunology. 2001; 126:143-150.

56. Kuiper HM, Brouwer M, Linsley PS and van Lier RA. Activated $\mathrm{T}$ cells can induce high levels of CTLA-4 expression on B cells. Journal of immunology. 1995; 155:1776-1783.
57. Baumgarth N, Jager GC, Herman OC and Herzenberg LA. CD4+ T cells derived from $B$ cell-deficient mice inhibit the establishment of peripheral B cell pools. Proceedings of the National Academy of Sciences of the United States of America. 2000; 97:4766-4771.

58. Billiau A and Matthys P. Interferon-gamma: a historical perspective. Cytokine Growth Factor Rev. 2009; 20:97-113.

59. Tortola L, Yadava K, Bachmann MF, Muller C, Kisielow J and Kopf M. IL-21 induces death of marginal zone B cells during chronic inflammation. Blood. 2010; 116:5200-5207.

60. Mehta DS, Wurster AL, Whitters MJ, Young DA, Collins $\mathrm{M}$ and Grusby MJ. IL-21 induces the apoptosis of resting and activated primary B cells. Journal of immunology. 2003; 170:4111-4118.

61. Wu HJ and Bondada S. CD72, a coreceptor with both positive and negative effects on B lymphocyte development and function. Journal of clinical immunology. 2009; 29:1221.

62. Parnes JR and Pan C. CD72, a negative regulator of B-cell responsiveness. Immunological reviews. 2000; 176:75-85.

63. Pan C, Baumgarth N and Parnes JR. CD72-deficient mice reveal nonredundant roles of CD72 in B cell development and activation. Immunity. 1999; 11:495-506.

64. Wu Y, Nadler MJ, Brennan LA, Gish GD, Timms JF, Fusaki N, Jongstra-Bilen J, Tada N, Pawson T, Wither $\mathrm{J}$, Neel BG and Hozumi N. The B-cell transmembrane protein CD72 binds to and is an in vivo substrate of the protein tyrosine phosphatase SHP-1. Current biology. 1998; 8:1009-1017.

65. Malek TR. The biology of interleukin-2. Annual review of immunology. 2008; 26:453-479.

66. Amu S, Gjertsson I, Tarkowski A and Brisslert M. B-cell CD25 expression in murine primary and secondary lymphoid tissue. Scand J Immunol. 2006; 64:482-492.

67. Amu S, Gjertsson I and Brisslert M. Functional characterization of murine CD25 expressing B cells. Scand J Immunol. 2010; 71:275-282.

68. Brisslert M, Bokarewa M, Larsson P, Wing K, Collins LV and Tarkowski A. Phenotypic and functional characterization of human CD25+ B cells. Immunology. 2006; 117:548-557.

69. Amu S and Brisslert M. Phenotype and function of CD25expressing B lymphocytes isolated from human umbilical cord blood. Clinical \& developmental immunology. 2011; 2011:481948.

70. Shimabukuro-Vornhagen A, Kondo E, Liebig T and von Bergwelt-Baildon M. Activated human B cells: stimulatory or tolerogenic antigen-presenting cells? Blood. 2009; 114:746-747; author reply 747.

71. Kessel A, Haj T, Peri R, Snir A, Melamed D, Sabo E and Toubi E. Human CD19(+)CD25(high) B regulatory cells suppress proliferation of CD4(+) $\mathrm{T}$ cells and enhance Foxp3 and CTLA-4 expression in T-regulatory cells. Autoimmunity reviews. 2012; 11:670-677. 
72. Oertelt S, Lian ZX, Cheng CM, Chuang YH, Padgett KA, He XS, Ridgway WM, Ansari AA, Coppel RL, Li MO, Flavell RA, Kronenberg M, Mackay IR and Gershwin ME. Anti-mitochondrial antibodies and primary biliary cirrhosis in TGF-beta receptor II dominant-negative mice. Journal of immunology. 2006; 177:1655-1660.

73. Deng YR, Ma HD, Tsuneyama K, Yang W, Wang YH, Lu FT, Liu CH, Liu P, He XS, Diehl AM, Gershwin ME and Lian ZX. STAT3-mediated attenuation of CClinduced mouse liver fibrosis by the protein kinase inhibitor sorafenib. Journal of autoimmunity. 2013; 46:25-34. doi: 10.1016/j.jaut.2013.07.008.

74. Yang GX, Lian ZX, Chuang YH, Moritoki Y, Lan RY, Wakabayashi K, Ansari AA, Flavell RA, Ridgway WM, Coppel RL, Tsuneyama K, Mackay IR and Gershwin ME. Adoptive transfer of $\mathrm{CD} 8(+) \mathrm{T}$ cells from transforming growth factor beta receptor type II (dominant negative form) induces autoimmune cholangitis in mice. Hepatology. 2008; 47:1974-1982.

75. Ray A and Dittel BN. Isolation of mouse peritoneal cavity cells. J Vis Exp. 2010; doi: 10.3791/1488.
76. Gao J, Ma X, Gu W, Fu M, An J, Xing Y, Gao T, Li W and Liu Y. Novel functions of murine B1 cells: active phagocytic and microbicidal abilities. European journal of immunology. 2012; 42:982-992.

77. Yoshida K, Yang GX, Zhang W, Tsuda M, Tsuneyama K, Moritoki Y, Ansari AA, Okazaki K, Lian ZX, Coppel RL, Mackay IR and Gershwin ME. Deletion of interleukin12 p40 suppresses autoimmune cholangitis in dominant negative transforming growth factor beta receptor type II mice. Hepatology. 2009; 50:1494-1500.

78. Kita H, Matsumura S, He X-S, Ansari AA, Lian Z-X, Van de Water J, Coppel RL, Kaplan MM and Gershwin ME. Quantitative and functional analysis of PDC-E2-specific autoreactive cytotoxic $\mathrm{T}$ lymphocytes in primary biliary cirrhosis. Journal of Clinical Investigation. 2002; 109:12311240 .

79. Wang F, Zhou Y, Fu B, Wu Y, Zhang R, Sun R, Tian Z and Wei $\mathrm{H}$. Molecular signatures and transcriptional regulatory networks of human immature decidual NK and mature peripheral NK cells. European journal of immunology. 2014; 44:2771-2784. 